\title{
Spalinowo-elektryczne układy napędowe dla krajowego lekkiego pojazdu szynowego Koncepcje i zalożenia
}

\begin{abstract}
$W$ artykule zaprezentowano wymagania $i$ wytyczne techniczno-eksploatacyjne dla lekkich pojazdów szynowych oraz spalinowo-elektrycznych uktadów napędowych. Przedstawiono koncepcje rozwiqzań układów do zabudowy podpodłogowej oraz zabudowy wewnatrzpojazdowej z wykorzystaniem wózków jedno- $i$ dwuosiowych. Ponadto przedstawiono założenia dla proponowanych do wykonania w kraju układów napędowych z wykorzystaniem zespołów pradotwórczych - silnik spalinowy + pradnica synchroniczna.

Artykut powstat w wyniku realizacji projektu badawczego nr 4 T12DO1227 pt.: „Spalinowoelektryczny napęd dla lekkich wieloczłonowych pojazdów szynowych”.
\end{abstract}

\section{WSTĘP}

Układ napędowy spalinowo-elektryczny stanowi zespół urządzeń służących do przeniesienia momentu obrotowego, wytwarzanego przez silnik spalinowy, na osie napędowe pojazdu.

W skład zespołu wchodzą: silniki spalinowe, prądnice, prostowniki, przekształtniki, silniki trakcyjne (prądu stałego lub zmiennego), wały przegubowe lub drążone, sprzęgła i przekładnie osiowe. Urządzenia te pośredniczą $\mathrm{w}$ przeniesieniu momentu (mocy) $\mathrm{i}$ łączą silnik spalinowy z napędowymi zestawami kołowymi.

Oprócz przeniesienia momentu układ napędowy winien spełniać dodatkowe zadanie, jakim jest pełne wykorzystanie mocy silnika $\mathrm{w}$ możliwie szerokim zakresie prędkości pojazdu, a więc jak najlepsze spełnienie wymagań trakcyjnych.

Ponadto układ napędowy winien zapewniać możliwość zmiany kierunku obrotów zestawu kołowego oraz umożliwiać odłączenie silnika spalinowego od osi w czasie rozruchu, postoju lub holowania, jak również cechować się zwartą budową pozwalającą na uzyskanie jak największej przestrzeni w członach pasażerskich [2].

Ze względu na zastosowany układ napędowy lekkie pojazdy szynowe, zwane autobusami szynowymi, dzieli się na [1]:

- z napędem spalinowym i przekładnią hydrauliczną (hydromechaniczną)

- z napędem spalinowo-elektrycznym i przekładnią elektryczną

- $\mathrm{z}$ napędem elektrycznym.

W artykule przedstawiono tylko układy napędowe z przekładnią elektryczną, w których zastosowane są lub będą zespoły prądotwórcze, a więc silniki spalinowe i prądnice, najczęściej synchroniczne. Takie układy napędowe znane i stosowane są od kilkudziesięciu lat $\mathrm{w}$ spalinowych zespołach trakcyjnych, a ostatnio od kilku lat wracają z powodzeniem w zastosowaniu również do napędów autobusów szynowych. Ich podstawową cechą jest przede wszystkim wysoka trwałość i niezawodność oraz możliwość realizowania wyższych mocy w ograniczonej przestrzeni.

W starszych rozwiązaniach, stosowanych w zasadzie w spalinowych zespołach trakcyjnych, całe układy napędowe zabudowane są pod ostojami członów napędowych. Przykładami mogą tu być zespoły serii VT610, BM/BS92 oraz VT/VS2E przeznaczone zasadniczo do obsługi ruchu regionalnego. Ich szczegółowe opisy wraz $\mathrm{z}$ charakterystykami przedstawiono w pracy [4].

W nowszych konstrukcjach lekkich pojazdów szynowych, a w zasadzie w autobusach szynowych, spotkać można dwie konfiguracje układów napędowych:

- układ podpodłogowy tzw. power-pack, na którym zabudowany jest tylko silnik spalinowy, prądnica oraz urządzenia $i$ aparaty gwarantujące prawidłową pracę zespołu prądotwórczego w tym chłodzenie i sterowanie. Układ power-pack podwieszony jest do ostoi członu napędowego z przodu pojazdu lub bezpośrednio za wózkiem napędowym, na którym zabudowane są silniki trakcyjne i przekładnie osiowe. Pozostałe aparaty i urządzenia wchodzące w skład układu napędowego lokalizowane są zarówno pod ostojac, wewnątrz pojazdu lub też na dachach np.: przekształtnik, hamulec elektrodynamiczny w tym oporniki oraz układy chłodzące. Przykładami autobusów z takimi rozwiązaniami są VT644 (Talent) oraz najnowsze autobusy firmy Bombardier serii DMU i EDMU [4], 
- układ wewnątrzpojazdowy, znajdujący się najczęściej między dwoma członami pasażerskimi lub też bezpośrednio za kabiną sterowniczą, co zwiększa bezpieczeństwo obsługi i pasażerów w przypadku ewentualnych kolizji. Taka zabudowa zespołów, maszyn i aparatów w wydzielonym członie daje następujące korzyści:

- lekką i prostą konstrukcję członów pasażerskich

- oszczędność w kosztach obsługi

- optymalną przyczepność osi napędowych

- oddzielenie źródła hałasu od przedziału pasażerskiego

- doskonały dostęp do aparatury trakcyjnej od wewnątrz i z zewnątrz pojazdu

- możliwość wymiany członu napędowego w ciaggu kilku godzin.

Ponadto zaletą autobusu o takiej konfiguracji jest również swoboda zestawiania większej liczby członów z miejscami dla pasażerów w zależności od potrzeb przewozowych i, co bardzo ważne, autobus po 35-letniej eksploatacji może być poddany recyklingowi, a część surowców użytych do jego budowy ponownie wykorzystanych. Przykładami takich rozwiązań są autobusy firmy Stadler serii GTW 2/6 i GTW 4/8 dla Polskich Kolei Państwowych [4].

\section{WYMAGANIA STAWIANE NOWOCZES- NYM LEKKIM POJAZDOM SZYNOWYM (AUTOBUSOM SZYNOWYM)}

Lekkie kolejowe pojazdy szynowe, dla wykonywania kolejowych regionalnych przewozów pasażerskich, winny charakteryzować się nowoczesnością konstrukcji, a jednocześnie posiadać sprawdzone i stosowane $\mathrm{w}$ przemyśle motoryzacyjnym i kolejnictwie podzespoły (dotyczy to w szczególności silnika spalinowego i przekładni). Ponadto autobus powinien charakteryzować się prostotą obsługi technicznej oraz niskimi kosztami eksploatacji.

Przewidywać należy również, że tego typu pojazdy mogą być wykonywane (zamawiane) w następujących konfiguracjach członów: s, s-s, s-d, s-d-s i d-s-d;

gdzie :

s - człon silnikowy tj. człon, w którym zabudowane są główne maszyny i zespoły układu napędowego, w tym wózki

d - człon doczepny, beznapędowy, oparty na wózkach tocznych.

Istotne $\mathrm{z}$ punktu widzenia napędu spalinowoelektrycznego są następujące wymagania i wytyczne dla lekkiego pojazdu szynowego:

- prędkość eksploatacyjna najczęściej $100 \div 120$ $\mathrm{km} / \mathrm{h}$

- skrajnia kinematyczna wg UIC 505-1 [5]
- wytrzymałość pudła - kategoria P3 wg normy PN-EN 12663 [9], z dodatkowym wyposażeniem w elementy pochłaniające energię zderzenia czołowego

- moc znamionowa silnika ok. $6,5 \div 8 \mathrm{~kW} / \mathrm{t}$ (nawet do $10 \mathrm{~kW} / \mathrm{t}$ )

- przyspieszenie rozruchu (przy pełnym obciążeniu) $\geq 0,5 \mathrm{~m} / \mathrm{s}^{2}$ (zazwyczaj $\left.0,6 \div 0,8\right)$

- opóźnienie hamowania ok. $1 \mathrm{~m} / \mathrm{s}^{2}$

- największe wzniesienie, na którym pojazd powinien ruszać z pełnym obciążeniem $>20 \div 30$ $\%$

- koła jezdne o profilu 28 UIC o szerokości obrzeża $135 \mathrm{~mm}$

- eksploatacyjny zakres temperatur otoczenia od $-30^{\circ} \mathrm{C}$ do $+40^{\circ} \mathrm{C}$

- poziom hałasu (zewnętrznego i wewnętrznego) przy pracującym silniku spalinowym i pozostałych maszynach zgodnie $\mathrm{z}$ normą $\mathrm{PN}-92 / \mathrm{K}$ 11000 [10]

- bezpieczeństwo ruchu podczas eksploatacji z maksymalnymi prędkościami wg UIC 518 [6] przy zachowaniu wskaźnika komfortu $<2,5 \mathrm{wg}$ UIC 515-0 [7]

- minimalny promień łuku warsztatowego $80 \div$ $100 \mathrm{~m}$

- minimalny promień łuku w eksploatacji $150 \mathrm{~m}$

- maksymalny nacisk zestawu kołowego na tor w stanie służbowym z pełnym obciążeniem 140 : $160 \mathrm{kN}$.

W zakresie wymagań dotyczących utrzymania pojazd powinien zapewniać (z punktu widzenia spalinowo-elektrycznego układu napędowego):

- żywotność przez okres ponad 30 lat

- prostą lokalizację uszkodzeń zespołów i podzespołów

- łatwą wykrywalność uszkodzeń i stanu osiagania granicznych parametrów technicznych poprzez zastosowanie elementów elektronicznego systemu diagnostyki (system elektronicznej diagnostyki podstawowych parametrów ekspolatacyjnych i lokalizacji uszkodzeń)

- budowę modułową umożliwiającą demontaż i montaż poszczególnych zespołów

- unifikację części dla ograniczenia niezbędnych narzędzi i oprzyrządowania

- współczynnik gotowości technicznej przekraczający $92 \%$

- minimalną liczbę przeglądów i napraw, a więc zwiększenie przebiegów między przeglądami i naprawami.

Ponadto należy zapewnić, aby konstrukcja, parametry techniczne i eksploatacyjne pojazdu spełniały wymagania przynależnych norm krajowych (w szczególności PN, PN-EN, BN i ZN), międzynarodowych 
IEC, EN oraz przepisów i zaleceń ERRI (ORE), kart UIC i Dyrektyw Parlamentu Europejskiego (Komisji Europejskich).

Oczywistym jest również, że każdy wyprodukowany lekki pojazd przed wejściem do eksploatacji powinien:

- zostać odebrany wg opracowanych Warunków Technicznych Odbioru

- przejść próby i badania stacjonarne i ruchowe wg opracowanego programu prób i badań zawierającego także eksploatację nadzorowaną (obserwowaną)

- spełniać warunki techniczne i wymagania zapewniające bezpieczeństwo ruchu i ochronę środowiska

- posiadać świadectwo dopuszczenia do eksploatacji typu pojazdu kolejowego

- posiadać świadectwo sprawności technicznej

- posiadać dokumentację techniczno-ruchowa, zawierającą opis pojazdu, instrukcję obsługi, instrukcję przeglądów i napraw oraz katalog części zamiennych

- posiadać dokumentację technologiczną systemu utrzymania.

\section{WYMAGANIA DLA UKLADÓW SPALINO- WO-ELEKTRYCZNYCH ORAZ ICH GLÓW- NYCH MASZYN I URZĄDZEŃ}

Konfiguracja układu napędowego powinna uwzględniać kryteria wyjściowe podane $\mathrm{w}$ [1].

Głównymi zespołami i maszynami w obu ww. konfiguracjach (niezależnie od zabudowanego wózka napędowego) są: silniki spalinowe, prądnice główne, prostowniki, przekształtniki trakcyjne, przetwornice statyczne, opornice hamulca elektrodynamicznego, silniki trakcyjne, przekładnie osiowe i zestawy kołowe napędowe.

Ponadto w układach tych zabudowane są urządzenia, układy i aparaty związane $\mathrm{z}$ silnikiem spalinowym, napędami pomocniczymi i hamulcem mechanicznym na wózkach [4].

\subsection{Wymagania dla maszyn i zespołów układów podpodłogowych}

Szczegółowe wymagania i wytyczne, za wyjątkiem ram mocujących, ram wózków z ich usprężynowaniem, tłumieniem, łożyskowaniem i przeniesieniem sił wzdłużnych dla poszczególnych głównych maszyn i zespołów, są następujące [4]:

Silnik spalinowy wysokoprężny o wtrysku bezpośrednim, w wersji leżącej, chłodzony cieczą i charakteryzujący się:

- mocą gwarantującą osiagnięcie prędkości 80 $\mathrm{km} / \mathrm{h}$ na wzniesieniach do $12 \%$
- emisją spalin zgodnie z Dyrektywą 26/2004 Parlamentu Europejskiego (Komisji Europejskiej) z 21.04.2004r., Rozporządzeniem Ministra Gospodarki i Pracy z 19.08.2005r. w sprawie szczegółowych wymagań dla silników spalinowych $\mathrm{w}$ zakresie emisji substancji toksycznych oraz z kartą UIC 624 [8]

- jednostkowym zużyciem paliwa do $200 \mathrm{~g} / \mathrm{kWh}$

- jednostkowym zużyciem oleju smarnego do $0,5 \%$ jednostkowego zużycia paliwa

- czasem pracy do przeglądu tłoków powyżej 10000 godz.

- czasem pracy do naprawy głównej powyżej 20000 godz.

Ponadto w układach związanych z silnikiem winien znajdować się zbiornik paliwa o pojemności wystarczającej do przebiegu około $1000 \mathrm{~km}$.

Prądnica główna trójfazowa synchroniczna, służąca do zasilania napędów i układów pomocnicznych, o następujących wymaganiach:

- wykonanie trakcyjne, chłodzenie powietrzem

- praca ze stałą optymalną prędkością obrotową

- wykonanie jednołożyskowe

- praca ciagła.

Dla układów podpodłogowych moc prądnicy powinna wynosić $220 \div 260 \mathrm{~kW}$ a prędkość obrotowa $1800 \div 2100$ obr/min.

Prostownik diodowy służący do wyprostowania napięcia trójfazowego prądnicy głównej, a następnie do zasilania trójfazowego przekształtnika napędowego. Przewidywane napięcie wejściowe winno wynosić $430 \div 500 \mathrm{~V} \mathrm{AC}$, wyjściowe $600 \div 750 \mathrm{~V} \mathrm{DC}$, moc około $300 \mathrm{~kW}$.

Prostownik powinien być chłodzony powietrzem wymuszonym (dopuszcza się chłodzenie naturalne) i być wyposażony $\mathrm{w}$ układ pomiaru temperatury elementów wewnętrznych.

Przeksztaltnik trakcyjny składający się $\mathrm{z}$ falownika napędowego i przekształtnika hamowania oporowego. Falownik zbudowany na tranzystorach IGBT będzie zasilał silnik trakcyjny, a przekształtnik hamowania w procesie zmniejszania prędkości wykorzysta energię do zasilania przetwornicy pomocniczej statycznej, a w przypadku nadmiaru mocy będzie wytracał energię w rezystorach hamowania.

Dla układów podpodłogowych należy przewidzieć falownik o mocy około $300 \mathrm{~kW}$, a przekształtnik hamowania oporowego o mocy około $230 \mathrm{~kW}$. Przekształtnik powinien posiadać chłodzenie naturalne lub wymuszone i być wyposażony w układ diagnostyki.

Przetwornica statyczna przeznaczona do zasilania napędów i urządzeń pomocniczych napięciem pośrednim przekształtnika. Może to być oddzielne urządzenie lub wchodzić w skład przekształtnika trakcyjnego. Proponowana zabudowa pod ostoją lub na dachu. 
Proponuje się przetwornice o mocy $10 \div 15 \mathrm{~kW} \mathrm{z}$ napięciem wyjściowym $3 x 400 \mathrm{~V} 50 \mathrm{~Hz}$ i $28 \mathrm{~V}$ DC.

Przetwornica winna być chłodzona naturalnie lub powietrzem wymuszonym oraz posiadać układ diagnostyki wewnętrznej.

Opornice hamulca (rezystory hamowania) służą do odbioru nadmiaru energii wytwarzanej podczas hamowania elektrodynamicznego. Przewidywana moc opornicy około $230 \mathrm{~kW}$, napięcie maksymalne $800 \mathrm{~V}$ a rezystancja ok. $2 \Omega$.

Opornica powinna być w wykonaniu trakcyjnym i zabudowana na dachu pojazdu.

Silnik trakcyjny asynchroniczny przeznaczony do napędu zestawu kołowego.

Podstawowe wymagania dla silnika są następujące:

- 3-fazowy z wirnikiem klatkowym w wykonaniu trakcyjnym, zasilany z falownika

- przystosowany do pracy poziomej ciagłej w obudowie zamkniętej o stopniu ochrony IP54 i izolacji klasy $\mathrm{H}$

- chłodzony wentylatorem własnym (dopuszcza się chłodzenie cieczą)

- zapewniający dowolny kierunek obrotów i przystosowany do pracy prądnicowej podczas hamowania elektrodynamicznego.

Podstawowe dane techniczne silnika przewidywanego do zabudowy podpodłogowej to: moc ok. 110 $\div 120 \mathrm{~kW}$ i prędkość obrotowa $1900 \mathrm{obr} / \mathrm{min}$, a maksymalnie ok. $4800 \mathrm{obr} / \mathrm{min}$.

Przekładnia osiowa winna cechować się płynną pracą wraz ze zmianą prędkości, odpornością na wszelkiego rodzaju przeciążenia, prostotą obsługi i napraw, wysoką trwałością i niskimi kosztami utrzymania oraz posiadać zwartą budowę i gabaryty umożliwiające zabudowę wzdłużną i poprzeczną.

W lekkich pojazdach szynowych można zastosować przekładnie jedno- lub dwustopniowe z kołami walcowymi lub stożkowymi, a ostateczny wybór rodzaju winien zależeć od głównych parametrów pojazdu oraz dysponowanego miejsca pod zabudowę.

Przyjmując średnicę toczną kół $840 \mathrm{~mm}$ (zużytych $780 \mathrm{~mm}$ ) przełożenie przekładni winno wynosić odpowiednio dla $\mathrm{v}=100 \mathrm{~km} / \mathrm{h} 6,24 \div 6,25$ a dla $\mathrm{v}=$ $120 \mathrm{~km} / \mathrm{h}$ nie więcej niż 5,2.

Zestaw kołowy napędowy o następujących ogólnych wymaganiach:

- średnica koła możliwie mała by zapewnić maksimum obniżonej podłogi w pojeździe, a jednocześnie spełnić wymagania $\mathrm{w}$ zakresie skrajni i dopuszczalnych nacisków zestawu na szynę (dla ø840 $\div 920 \mathrm{~mm}-20$ t, a dla $\varnothing 760 \div 840$ $\mathrm{mm}-18 \mathrm{t}$ )

- minimalna masa nieodsprężynowana

- duża trwałość, a więc duży przebieg do przetoczenia
- oś standardowa z czopami łożyskowymi o średnicy ø130 mm.

Dla układów napędowych preferowane winny być zestawy kołowe (toczne i napędowe) $\mathrm{z}$ kołami bezobręczowymi o średnicy $ø 840 \mathrm{~mm}$, wykonane z materiału R8T lub R9T.

Hamulec dla lekkiego pojazdu szynowego winien spełniać następujące wymagania:

- umożliwić zatrzymanie w każdych warunkach eksploatacyjnych, a więc $\mathrm{z} \mathrm{v}=100 \mathrm{~km} / \mathrm{h}$ na drodze $600(700) \mathrm{m}$, a z v $=120 \mathrm{~km} / \mathrm{h}$ na drodze $800 \mathrm{~m}$

- zapewnić utrzymanie pojazdu na wzniesieniu $45 \%$

- posiadać elektroniczny układ przeciwpoślizgowy działający przy ruszaniu i hamowaniu

- posiadać okładziny cierne nie zawierające azbestu

- posiadać system wewnętrzny umożliwiający przeprowadzenie samotestu przed wyjazdem na trasę.

W lekkich pojazdach szynowych, niezależnie od zastosowanych wózków, hamulcem mechanicznym może być zarówno hamulec klockowy jak i tarczowy, przy czym tarcze hamulcowe mogą być zabudowane zarówno na kole jezdnym osi zestawu kołowego lub na wale drążonym, jeżeli taki układ przeniesienia napędu z silnika trakcyjnego na zestaw kołowy będzie zastosowany.

Dokonując wyboru zabudowy tarcz hamulcowych należy brać pod uwagę:

- możliwość zabudowy na wózkach jedno- i dwuosiowych

- unifikację zabudowy na wózkach tocznych i napędowych

- możliwość zastosowania obniżonej podłogi nad wózkiem tocznym

- zwartość konstrukcji tj. jak najmniejszą odległość między osią zestawu kołowego a osią silnika trakcyjnego.

W układach napędowych lekkich pojazdów preferowany byłby układ hamulca tarczowego (z tarczami zabudowanymi na kołach zestawów kołowych), przy czym ilość tarcz zależeć winna od szczegółowych obliczeń układu.

Jeżeli wymagają tego warunki eksploatacyjne należy również dopuścić zastosowanie tzw. klocka czyszczącego, zwłaszcza w obszarach eksploatacji z automatycznymi urządzeniami sterowania ruchem kolejowym, dla pojazdów o bazie przekraczającej $6 \mathrm{~m}$ (odległości między wózkami jednoosiowymi).

\subsection{Wymagania dla maszyn i zespołów w zabudo- wie wewnątrzpojazdowej}

Szczegółowe wymagania i wytyczne dla poszczególnych maszyn i zespołów $w$ zabudowie wewnątrzpojazdowej są następujące: 
Silnik spalinowy o wymaganiach jak w pkt. 3.1. przy czym winna być zastosowana wersja stojąca (układ cylindrów rzędowy lub widlasty), zabudowany na wspólnej ramie z prądnicą główną tworząc zespół prądotwórczy. Rozważyć należy zwiększoną (około dwukrotnie) moc silnika, zapewniając $w$ ten sposób pełne jego wykorzystanie w przypadku napędów zabudowanych na wszystkich zestawach kołowych.

Prądnica glówna o wymaganiach jak w pkt. 3.1. o mocy $550 \div 600 \mathrm{~kW}$ i obrotach silnika spalinowego, połączona elastycznie (sprzęgło elastyczne) lub sztywno za pośrednictwem kołnierza.

Prostownik o wymaganiach jak w pkt. 3.1. o zwiększonej mocy tj. $550 \div 600 \mathrm{~kW}$.

Przeksztaltnik trakcyjny identyczny jak w pkt. 3.1. dla zachowania tej samej konfiguracji układu napędowego. W przypadku zastosowania tylko jednego wózka napędowego dwuosiowego i silników trakcyjnych o zwiększonej mocy $(230 \div 280 \mathrm{~kW})$ wymagane byłoby zastosowanie przekształtnika trakcyjnego o mocy falownika do $600 \mathrm{~kW}$ i przekształtnika hamowania oporowego do około $500 \mathrm{~kW}$, przy zachowaniu tych samych parametrów napięciowoprądowych.

Przetwornica statyczna o mocy $20 \div 25 \mathrm{~kW}$ przy zachowaniu pozostałych wymagań jak w pkt. 3.1. a biorąc pod uwagę zastosowanie tylko jednego przekształtnika trakcyjnego, moc przetwornicy winna być zwiększona do $50 \mathrm{~kW}$.

Wymagania dla pozostałych maszyn układu napedowego, a więc opornic hamowania oraz silników trakcyjnych winny być identyczne jak przedstawiono w pkt. 3.1., przy czym ich moce wyjściowe w przypadku zastosowania tylko jednego przekształtnika trakcyjnego (napędowego) oraz jednego wózka napędowego powinny być zwiększone dwukrotnie.

Pozostałe zespoły i urządzenia zastosowane w konfiguracji wewnątrzpojazdowej napędu, a więc przekładnie osiowe, zestawy kołowe i układy hamulcowe winny spełniać wymagania i wytyczne podane w pkt. 3.1.

\section{KONCEPCJE I ZALOŻENIA PROJEKTO- WE DLA KRAJOWYCH SPALINOWO - ELEKTRYCZNYCH NAPĘDÓW LEKKICH POJAZDÓW SZYNOWYCH}

Analiza krajowego rynku wykazała, że poza spalinowymi zespołami trakcyjnymi (prawie 40-letnimi) sprowadzanymi z Niemiec, eksploatowane są autobusy szynowe z układami napędowymi opartymi o silniki spalinowe i przekładnie hydrauliczne (hydromechaniczne), „Pesy” Bydgoszcz, ZNTK-Poznań i byłego Kolzamu - Racibórz. Do grona wymienionych pretenduje również Bumar-Fablok Chrzanów.

Obecnie coraz częściej potencjalni Użytkownicy zgłaszają zainteresowanie autobusami szynowymi z układami napędowymi spalinowo-elektrycznymi. Tak więc już teraz, wychodząc naprzeciw oczekiwaniom należałoby opracować projekty techniczne i przebadać takie układy w miarę możliwości oparte o maszyny, zespoły i urządzenia produkowane lub możliwe do produkcji w kraju.

Jako podstawę należy przyjąć założenie ukierunkowujące prace nad rozwiązaniem następujących układów:

- do zabudowy podpodłogowej tzw. Power-Pack

- do zabudowy wewnątrz pojazdu.

Pierwszy z tych układów może być zamienny z dotychczasowymi z przekładnią hydrauliczną, natomiast dla drugiego należałoby zaprojektować przedział (moduł) napędowy, najlepiej wydzielony $z$ dostępem do niego od zewnątrz i wewnątrz.

\subsection{Koncepcje i zalożenia projektowe dla lekkich pojazdów szynowych ze spalinowo-elektrycz- nymi ukladami napędowymi}

Koncepcje i założenia spalinowo-elektrycznych układów napędowych nie mogą abstrahować od budowy samych lekkich pojazdów, dla których układy będą projektowane i wdrażane. Dla warunków krajowych przyjęto układ napędowy, który składać się będzie z: silnika spalinowego, prądnicy synchronicznej, przekształtnika tranzystorowego (falownik, przekształtnik hamowania), silników trakcyjnych asynchronicznych, przekładni osiowych i zestawów kołowych napędowych.

W związku z tym, że istnieją już zaprojektowane i eksploatowane autobusy proponuje się wykorzystać jednoczłon typu $211 \mathrm{M}$, dwuczłon $212 \mathrm{M}$ i trójczłon $210 \mathrm{M}$ oraz ich nowe (wydłużone) warianty do zabudowy układów podpodłogowych zarówno w oparciu o dotychczasowe wózki jednoosiowe jak i nowe wózki dwuosiowe, specjalnie zaprojektowane.

Dla zabudowy wewnętrznej układów należy przewidywać autobusy szynowe (jedno-, dwu- i trójczłonowe) o wydłużonym nadwoziu i zwiększonej liczbie miejsc siedzących. Ogólne widoki wybranych i proponowanych autobusów szynowych dla zabudowy proponowanych układów napędowych przedstawiono na rys. $1 \div 3$.

Reasumując, dla rozwijanych układów napędowych można zaproponować następujące konfiguracje wieloczłonowych autobusów szynowych:

- autobusy dotychczasowe $\mathrm{z}$ wózkiem jednoosiowym:

- jednoczłon z jednym wózkiem napędowym i jednym tocznym- układ osi $\left(\mathrm{A}^{\prime}+1\right)$

- dwuczłon z dwoma wózkami napędowymi i dwoma tocznymi - układ osi $(\mathrm{A}+1)-(1+\mathrm{A})$

- trójczłon z dwoma wózkami napędowymi i czterema wózkami tocznymi w układzie osi $-\left(\mathrm{A}^{\prime}+1\right)-(1+1)-\left(1+\mathrm{A}^{\prime}\right)$ 
- autobusy do zaprojektowania z wózkami jednoi dwuosiowymi:

- jednoczłon $\mathrm{z}$ jednym wózkiem napędowym $\mathrm{i}$ jednym tocznym - układ osi $\left(\mathrm{B}_{0}-2\right)$

- dwuczłon zarówno z wózkami jednoosiowymi i dwuosiowymi o układach osi $\left(\mathrm{B}_{0}+1\right)\left(1+\mathrm{B}_{\mathrm{o}}\right) ;\left(\mathrm{B}_{0}+2\right)-\left(2+\mathrm{B}_{\mathrm{o}}\right) ; \mathrm{B}_{0}-2-\mathrm{B}_{\mathrm{o}}$
- trójczłon z wózkami jedonosiowymi i dwuosiowymi o układach osi $\left(\mathrm{B}_{0}+1\right)+(1-1)$ $\left(1+\mathrm{B}_{0}\right) ;\left(\mathrm{B}_{\mathrm{o}}+2\right)-(1-2+1-2)-\left(2+\mathrm{B}_{\mathrm{o}}\right) ; \mathrm{B}_{0}-2-2-\mathrm{B}_{\mathrm{o}}$.

Ostateczny wybór konfiguracji oraz szczegółowych parametrów autobusów zależeć będzie od precyzyjnych wymagań przyszłego Użytkownika i zadań do spełnienia $\mathrm{w}$ określonych warunkach eksploatacyjnych.
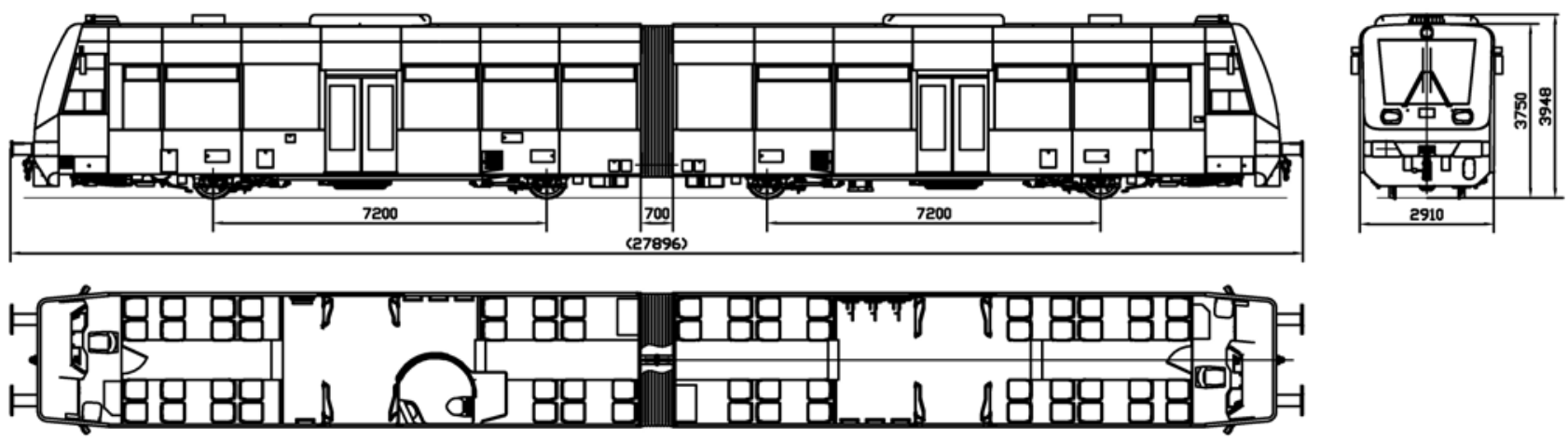

Rys.1. Ogólny widok autobusu dwuczłonowego typu 212M o układzie osi (A’+1)-(1+A’)
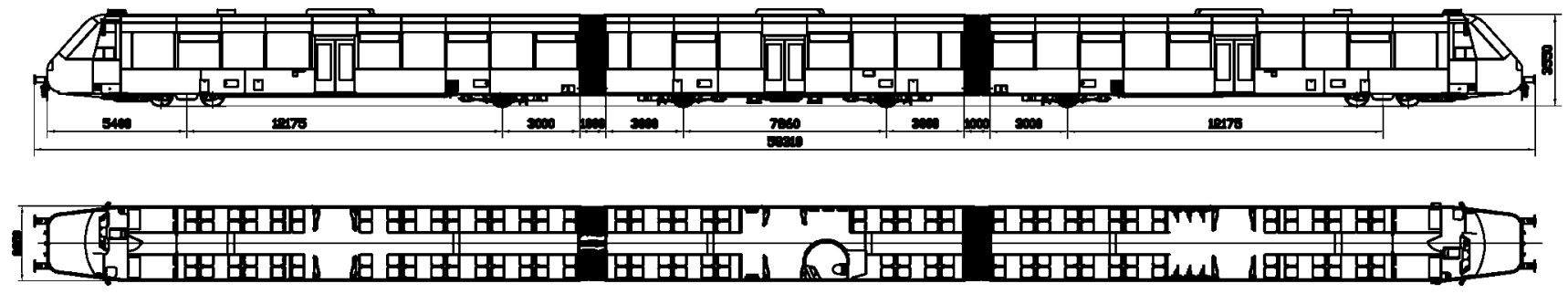

Rys.2. Ogólny widok autobusu trójczłonowego o układzie osi $\left(\mathrm{B}_{\mathrm{o}}+1\right)-(1+1)-\left(1+\mathrm{B}_{\mathrm{o}}\right)$
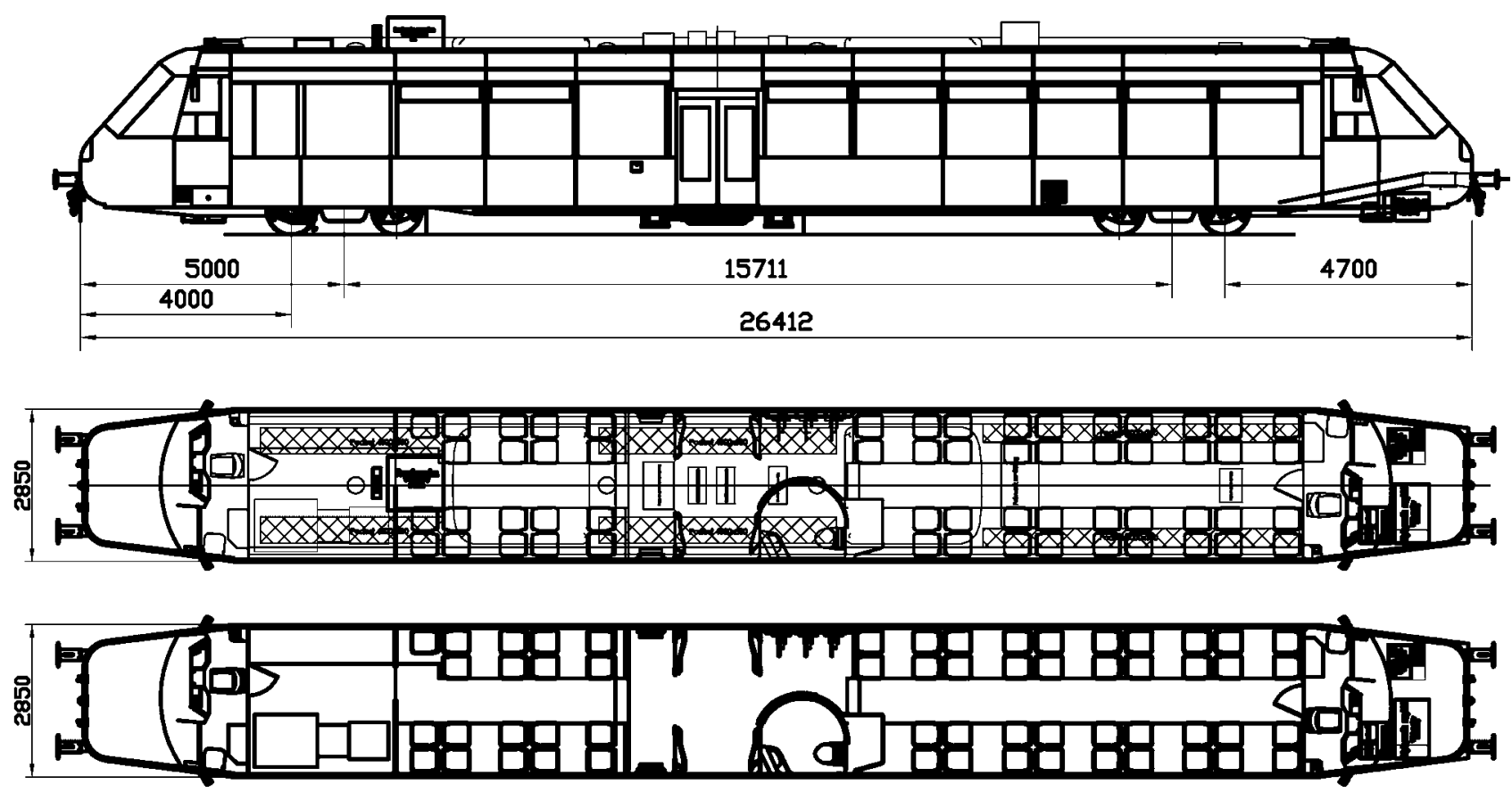

Rys.3. Ogólny widok autobusu jednoczłonowego w wersji wydłużonej o układzie osi ( $\left.\mathrm{B}_{\mathrm{o}}-2\right)$ 


\subsection{Koncepcje i założenia projektowe dla spalino- wo-elektrycznego układu napędowego do za- budowy podpodłogowej}

Podjęcie decyzji o opracowaniu koncepcji i założeń układu wiąże się z rozważeniem następującego zagadnienia: czy zespoły i maszyny wchodzące $\mathrm{w}$ układ napędowy mają być na tyle uniwersalne, że spełnić mogą wymagania wszystkich wariantów pojazdów proponowanych pod zabudowę, czy też zespoły te będą dobierane indywidualnie dla każdego typu pojazdu.

W pojazdach jednoczłonowych, przy połowie osi napędowych i spełnieniu określonych parametrów rozruchowych, może to prowadzić w dwu- i trójczłonach do niewykorzystania mocy takiego zespołu przy zabezpieczeniu podobnej ilości osi napędowych lub zwiększonej mocy silników trakcyjnych.

Można więc również rozważyć zastosowanie jednego typu zespołu napędowego (falownik-silnik trakcyjny) przy obniżonych parametrach rozruchu.

Decyzja powinna zależeć przede wszystkim od przewidywanej wielkości produkcji, ponieważ wysokie koszty wyposażenia technologicznego dla produkcji maszyn będą wpływać na ocenę całego wyposażenia elektrycznego, a trzeba brać również od uwage pozostałe elementy zespołu elektrycznego i całą część mechaniczną.

Do rozważań projektowych spalinowo-elektrycznych układów napędowych należałoby przewidzieć następujace główne parametry pojazdów [3]:

- masa własna:

- dla pojazdu jednoczłonowego $23 \div 25 \mathrm{Mg}$

- dla pojazdu dwuczłonowego $44 \div 46 \mathrm{Mg}$

- dla pojazdu trójczłonowego $63 \div 65 \mathrm{Mg}$

- prędkość eksploatacyjna $100 \div 120 \mathrm{~km} / \mathrm{h}$

- przyspieszenie rozruchu $0,6 \div 0,8 \mathrm{~m} / \mathrm{s}^{2}$.

Uzyskanie tych parametrów można osiagnąć dla następujących głównych danych układów napędowych:

- dla pojazdu jednoczłonowego:

- moc max. silnika spalinowego (z uwzględnieniem $40 \%$ przeciążalności) $250 \div 300$ $\mathrm{kW}$

- moc obwodów pomocniczych $15 \mathrm{~kW}$

- moc znamionowa silników trakcyjnych 200 $\mathrm{kW}$, a więc dla pojazdów $\mathrm{z}$ wózkami jednoosiowymi obie osie napędowe $\mathrm{z}$ silnikami o mocy $100 \mathrm{~kW}$, a dla pojazdów z wózkami dwuosiowymi jeden wózek napędowy, a jeden toczny

- dla pojazdu dwuczłonowego:

- moc max. silników (silnika) spalinowych ok. $500 \mathrm{~kW}$

- moc obwodów pomocniczych $20 \mathrm{~kW}$

- moc znamionowa silników trakcyjnych 350 $\div 400 \mathrm{~kW}$, a więc dla pojazdu z wózkami jednoosiowymi wszystkie osie napędowe przy mocy silnika trakcyjnego ok. 100 $\mathrm{kW}$ lub dwie osie napędowe jednego członu z silnikami trakcyjnymi o mocy ok. $170 \mathrm{~kW}$ każdy (drugi człon miałby tylko wózki toczne), a dla pojazdu z wózkami dwuosiowymi należy przewidzieć dwa wózki napędowe z silnikami o mocy $100 \mathrm{~kW}$, jeden (lub dwa) wózek toczny

- dla pojazdu trójczłonowego:

- moc max. silnika (silników) spalinowego ok. $700 \mathrm{~kW}$

- $\quad$ moc obwodów pomocniczych $25 \div 30$ $\mathrm{kW}$

- moc znamionowa silników trakcyjnych ok. $500 \mathrm{~kW}$, przy czym przy zastosowaniu wózków jednoosiowych należy przewidzieć cztery osie napędowe i dwie toczne, a przy zastosowaniu wózków dwuosiowych dwa wózki napędowe i dwa wózki toczne $\mathrm{z}$ silnikami o mocy podwyższonej do ok. $150 \mathrm{~kW}$.

Silniki trakcyjne o mocy $100 \mathrm{~kW}$ mogą być dostarczone przez producenta krajowego, natomiast silniki o wyższej mocy rzędu $120 \div 150 \mathrm{~kW}$ wymagają opracowania konstrukcyjnego.

Dla proponowanych konfiguracji schemat ideowy przedstawiono na rys.4.

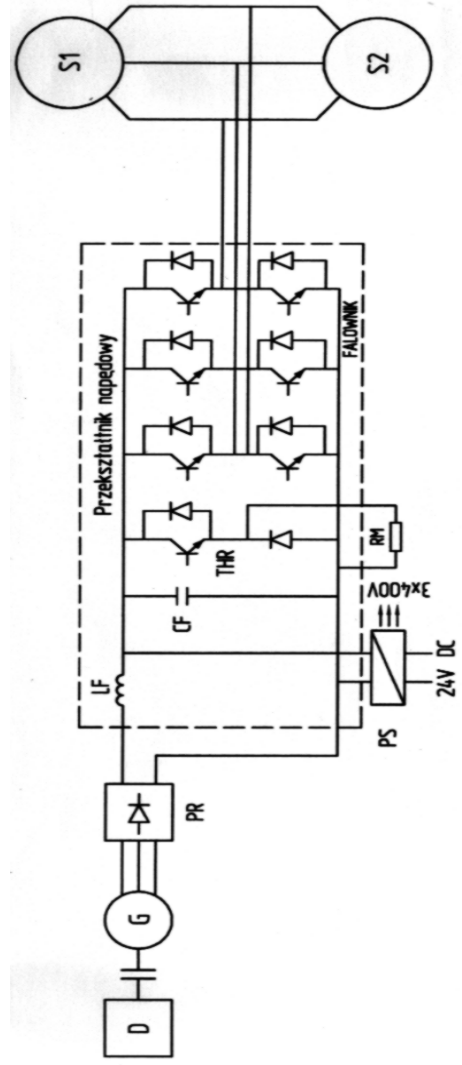

Rys.4. Schemat ideowy układu elektrycznego lekkiego pojazdu szynowego: D - silnik spalinowy; $\mathrm{G}$ - trójfazowa prądnica synchroniczna; PR - prostownik; LF - dławik filtru; CF - kondensator filtru; THR - tranzystor hamowania oporowego; RM - rezystor hamowania oporowego; S1S2 - silnik asynchroniczny; PS - przetwornica statyczna. 
Układ taki składałby się z następujących maszyn i zespołów o parametrach [3]:

- silnika spalinowego o mocy ok. $300 \mathrm{~kW}$

- prądnicy trójfazowej (synchronicznej) o mocy ok. $250 \mathrm{~kW}$

- prostownika diodowego

- falownika napędowego o mocy maksymalnej $300 \mathrm{~kW}$

- przekształtnika hamowania oporowego o mocy $200 \mathrm{~kW}$

- opornicy hamowania $200 \mathrm{~kW}$

- silników trakcyjnych asynchronicznych o mocy 100 kW każdy

- przetwornicy statycznej $660 \mathrm{~V} / 3 \times 400 \mathrm{~V} / 24 \mathrm{~V}$ DC o mocy $15 \mathrm{~kW}$ (dla wieloczłonów $20 \div 25$ $\mathrm{kW})$.

Należy pamiętać o tym, że w przypadku podwyższonych mocy silników trakcyjnych ulegają zmianie pozostałe parametry mocy.

W zaprezentowanym układzie silnik spalinowy pracować będzie ze stałą optymalną prędkością obrotową napędzając sprzężoną $\mathrm{z}$ nim jednołożyskową prądnicę synchroniczną. Napięcie prądnicy regulowane będzie na poziomie $430 \div 500 \mathrm{~V}$, a po wyprostowaniu napięcie dla członu pośredniego wyniesie 600 $\div 750$ V. Dobór wartości napięcia dla członu pośredniego będzie zależny od ostatecznego doboru asynchronicznych silników trakcyjnych. Falownik trójfazowy IGBT zasilać będzie dwa silniki asynchroniczne.

Falownik zbudowany winien być $\mathrm{z}$ trzech modułów IGBT pracujących z częstotliwością $1,2 \div 2 \mathrm{kHz}$ kształtujących sinusoidę prą̧ów fazowych $0 \div$ $140 \mathrm{~Hz}$, odpowiadającą prędkości $0 \div 120 \mathrm{~km} / \mathrm{h}$.

Podczas hamowania elektrodynamicznego napięcie członu pośredniego będzie wyższe o około $50 \div 100 \mathrm{~V}$ tak, aby część zwracanej energii pobierała przetwornica statyczna. Pozostała energia hamowania tracona będzie w opornicy.

Przetwornica statyczna zasilana będzie $\mathrm{z}$ napięcia pośredniego, przetwarzając je na $3 x 400 \mathrm{~V}-50 \mathrm{~Hz}$ do zasilania między innymi silników wentylatorów i sprężarek oraz $24 \mathrm{~V}$ do zasilania układów rozruchu, sterowania, oświetlenia wewnętrznego i zewnętrznego, zasilania urządzeń radiołączności i bezpieczeństwa ruchu, wycieraczek i spryskiwaczy oraz ładowania baterii akumulatorów.
Układ napędowy, a w zasadzie zespół prądnica silniki trakcyjne powinien być tak dobrany, by zapewnić $40 \div 50 \%$ przeciążenie podczas rozruchu.

Ponadto prądnica synchroniczna trójfazowa powinna być wykonana jako jednołożyskowa sprzęgnięta $\mathrm{z}$ silnikiem spalinowym, natomiast prostownik diodowy - falownik mogą być we wspólnej obudowie $\mathrm{z}$ chłodzeniem powietrznym lub zanurzone w kadzi z olejem.

Dla proponowanych wariantów napędu moc silnika trakcyjnego powinna wynosić $100 \div 170 \mathrm{~kW}$, a więc najlepszym rozwiązaniem byłoby opracowanie jednego typu silnika o mocy ok. $150 \mathrm{~kW}$. Długość i średnica silnika będzie wynikać z konstrukcji wózków napędowych. Silniki powinny być wykonane jako bezkadłubowe $\mathrm{z}$ chłodzeniem poprzez otwory w blachach stojana.

W układach podpodłogowych można zastosować zarówno wózki jednoosiowe jak i dwuosiowe. Pierwsze z nich można rozwijać na bazie dotychczasowych wózków jednoosiowych zastosowanych w autobusach szynowych $211 \mathrm{M}$ i $212 \mathrm{M}$; drugie natomiast w oparciu o zaprojektowane już wózki dla elektrycznych zespołów trakcyjnych oraz tramwajów [4].

Propozycje rozwiązań układów przeniesienia napędów z silnika trakcyjnego na zestaw kołowy dla wózków jednoosiowych przedstawiono na rys.5 i 6 . Rys. 5 przedstawia pełny schemat układu napędowego, a na rys. 6 ograniczono się do schematycznego zaprezentowania tylko zespołów wózkowych.

W propozycji pierwszej (rys.5) silnik trakcyjny zawieszony będzie systemem tramwajowym (,za nos"), a przeniesienie momentu obrotowego z wału wirnika silnika trakcyjnego na zestaw kołowy realizować będzie jednostopniowa przekładnia osiowa, z 
kołami walcowymi o zębach prostych. Obudowa przekładni mocowana będzie do silnika trakcyjnego i w połączeniu z zestawem posiadać będzie uszczelnienia labiryntowe.

Propozycja druga (rys.6a) to całkowicie odsprężynowany na ramie wózka silnik trakcyjny. Moment obrotowy z wału silnika na zestaw kołowy przenoszony będzie poprzez sprzęgło i przekładnię.

Sprzęgło zębate dwuprzegubowe osadzone będzie na końcówce stożkowej wału silnika oraz na końcówce stożkowej wału małego koła zębatego.

Przekładnia będzie częściowo odsprężynowana, opierając się z jednej strony na osi zestawu kołowego, $\mathrm{z}$ drugiej natomiast będzie umieszczona na ramie wózka. Przekładnie będą tworzyć koła walcowe o zębach prostych lub skośnych (z dużym kołem osadzonym bezpośrednio na osi zestawu) zabudowane $\mathrm{w}$ obudowie opierającej się za pośrednictwem łożysk tocznych na osi zestawu kołowego.

Rys.6b prezentuje trzecią propozycję przeniesienia napędu, w której zakłada się kołnierzowe połączenia przekładni i silnika trakcyjnego całkowicie odsprężynowanych na ramie wózka. Napęd z wału silnika na przekładnię przenoszony będzie poprzez sprzęgło membramowe. Wał silnika ułożyskowany będzie jednostronnie. Drugą stronę stanowić będzie jako podporę sprzęgło membramowe. Przekładnia będzie dwustopniowa walcowa, czołowa, z kołami o zębach prostych lub skośnych.

Moment obrotowy z przekładni przekazywany będzie na zestaw kołowy poprzez dwuprzegubowe elastyczne, bezluzowe sprzęgło, które ponadto skompensuje duże przemieszczenia wałów. Sprzęgło $\mathrm{z}$ jednej strony połączone będzie $\mathrm{z}$ wałem drążonym, a $\mathrm{z}$ drugiej strony z piastą osadzoną na osi zestawu kołowego.

W propozycji czwartej (rys.6c) silnik trakcyjny zawieszony będzie na ramie wózka, a więc będzie całkowicie odsprężynowany. Przekładnia osiowa będzie jednostopniowa, stożkowa, czołowa z kołami o zębach łukowych, całkowicie oparta za pośrednictwem łożysk tocznych na osi zestawu kołowego. Przekładnia połączona będzie z ramą wózka za pomocą drażka reakcyjnego. Moment obrotowy z silnika trakcyjnego na przekładnię przekazywany będzie za pośrednictwem wału przegubowego (Cardana).

a)

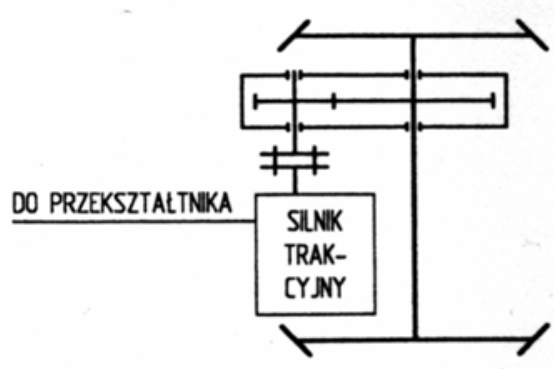

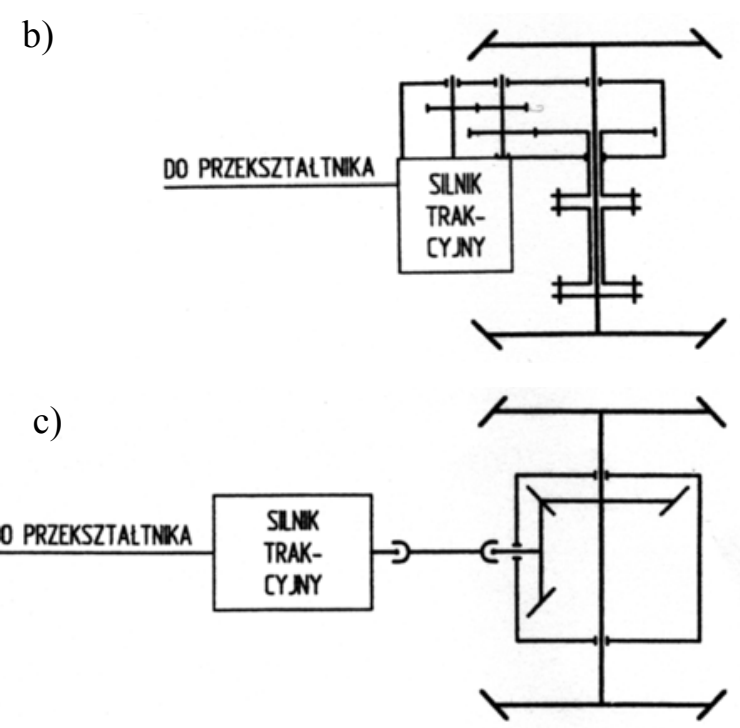

Rys.6. Schematy przeniesienia napędu z silnika trakcyjnego na zestaw kołowy dla wózków jednoosiowych

$\mathrm{a}-\mathrm{z}$ jednostopniową przekładnią z kołami walcowymi połączoną z silnikiem trakcyjnym sprzęgłem zębatym

$\mathrm{b}-\mathrm{z}$ dwustopniową przekładnią z kołami walcowymi, wałem drażonym i kołnierzowym połączeniem przekładni z silnikiem trakcyjnym

$\mathrm{c}-\mathrm{z}$ jednostopniową przekładnią osiową z kołami stożkowymi

Propozycje rozwiązań przeniesienia napędu dla wózków dwuosiowych przedstawiono schematycznie na rys. 7 i 8 , przy czym rys. 7 przedstawia schematycznie pełen układ napędowy, natomiast na rys. 8 przedstawiono schematy przeniesienia napędu ograniczając się do zespołów zabudowanych w obrębie wózków napędowych.

Na rys.7 do przekładni stożkowej wprowadzono dodatkowy drugi stopień przełożenia, realizowany poprzez przekładnię z kołami walcowymi. Obie przekładnie zabudowane są w jednej obudowie, a zastosowanie dodatkowej przekładni może umożliwić zwiększenie przełożenia.

Schemat na rys.8a jest podwójnym układem prezentowanym już na rys.6c.

$\mathrm{Na}$ rys.8b przedstawiono propozycję układu napędowego identyczną (podwójną) jak już prezentowano na rys.6a dla wózka jednoosiowego.

Rys.8c prezentuje schemat napędu różniący się od rys.8b tylko zastosowaniem przekładni walcowej dwustopniowej dla uzyskania większej swobody w kształtowaniu przełożenia.

$\mathrm{Na}$ rys.8d przedstawiono natomiast schemat układu o budowie identycznej jak dla wózka jednoosiowego pokazanego na rys.6b.

Niezależnie od przedstawionych propozycji można proponować inne rozwiązania np.z silnikiem trakcyjnym zawieszonym pod ostoja pudła jak i z silnikiem przenoszącym napęd bezpośrednio na oś, z wirnikiem osadzonym na wale drążonym. 
O wyborze jednej z propozycji, jak również wyborze wózka zdecyduje przede wszystkim konfiguracja lekkiego pojazdu szynowego, jego trwałość, niezawodność i żywotność, a głównie cena.

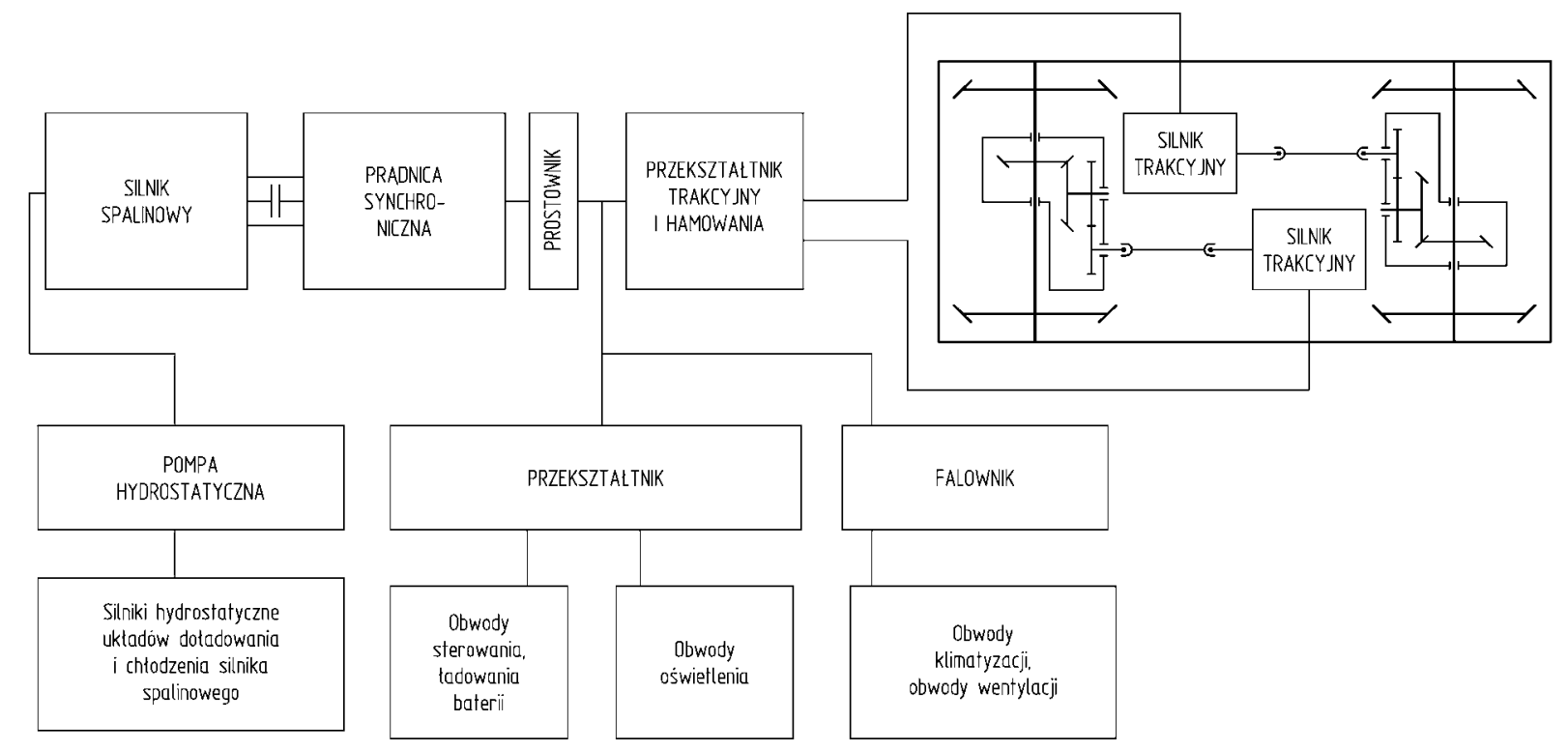

Rys.7. Schemat przeniesienia napędu z wykorzystaniem osiowej przekładni dwustopniowej (walcowej i stożkowej)

a)

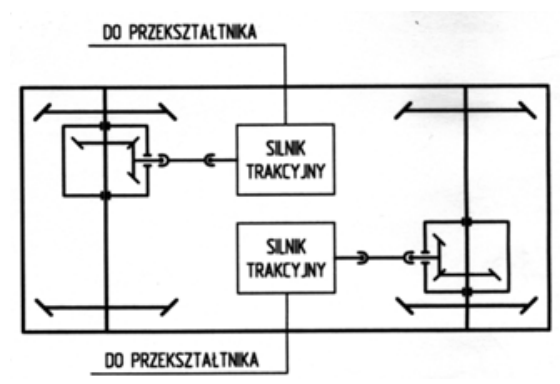

c)

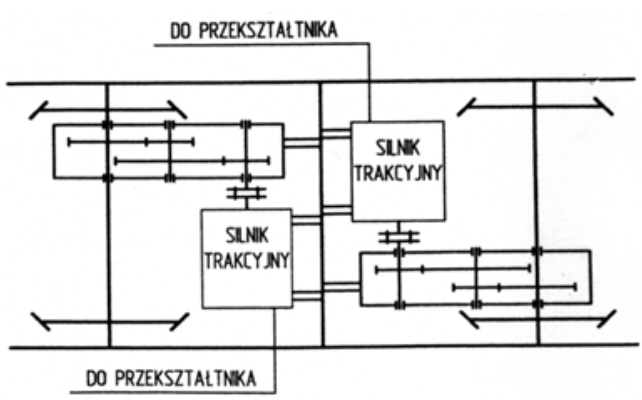

b)

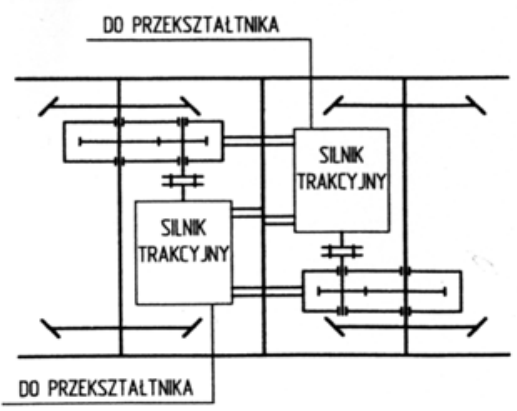

d)

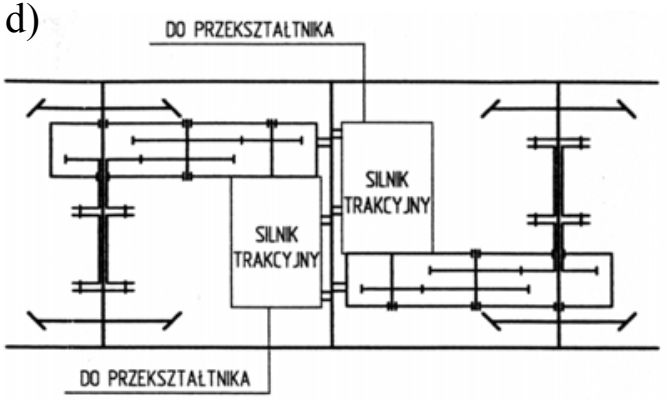

Rys.8. Schematy przeniesienia napędu z silników trakcyjnych na zestawy kołowe dla wózka dwuosiowego a - z przekładnią jednostopniową z kołami stożkowymi

b - z przekładnią jednostopniową $\mathrm{z}$ kołami walcowymi i połączeniem silnika trakcyjnego z przekładnią za pośrednictwem sprzęgła zębatego

c - z przekładnią dwustopniową z kołami walcowymi i połączeniem przekładni z silnikiem trakcyjnym za pośrednictwem sprzęgła zębatego

$\mathrm{d}-\mathrm{z}$ przekładnią dwustopniową z kołami walcowymi i wałem drążonym oraz kołnierzowym połączeniem przekładni z silnikiem trakcyjnym 
Na rys.9 przedstawiono koncepcję power-pack, a na rys.10 i 11 wybrane koncepcje wózka jednoosiowego i dwuosiowego.
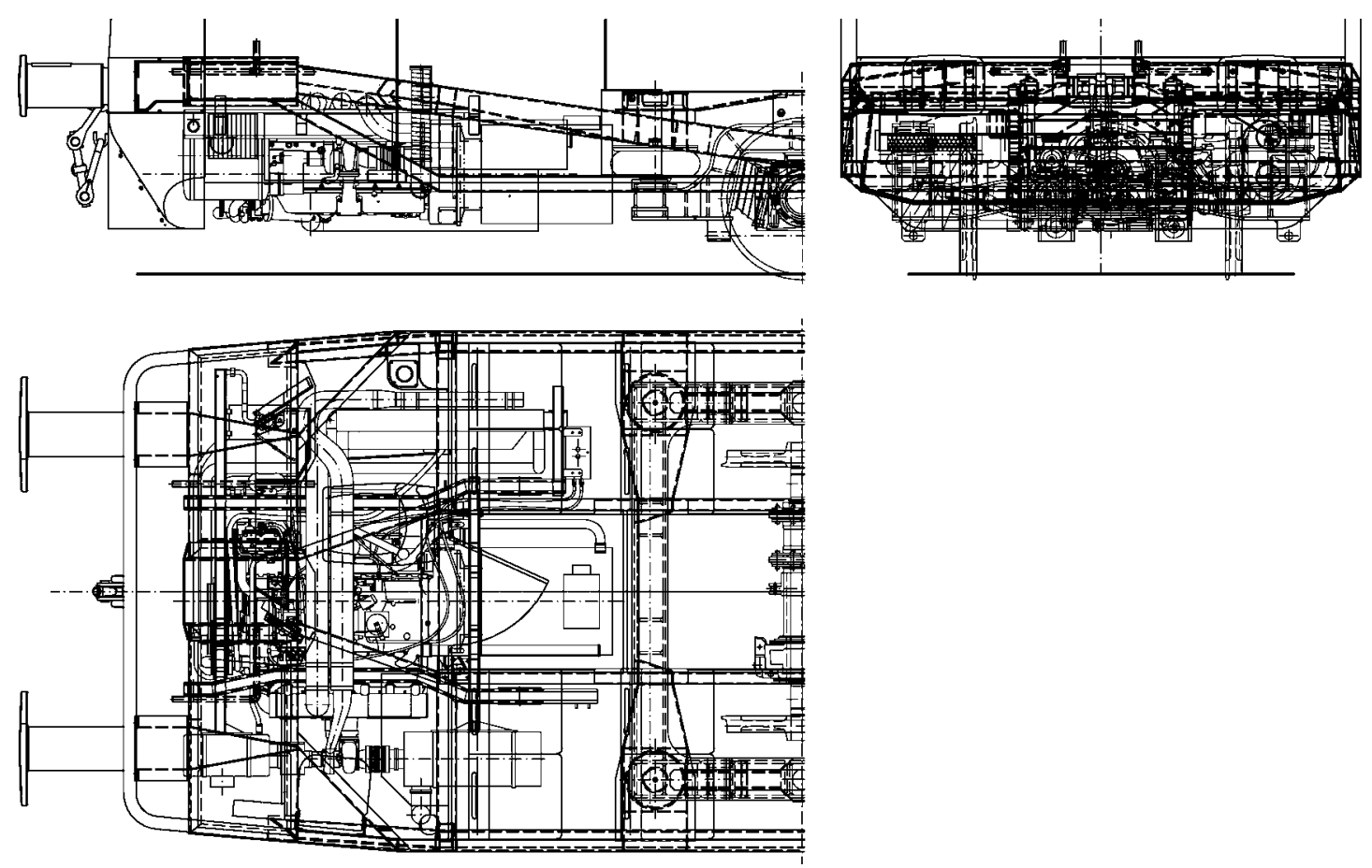

Rys.9. Koncepcja zabudowy power-pack z przodu lekkiego pojazdu szynowego (widoczny również wózek jednoosiowy z usprężynowaniem i krótkim wałem drążonym)
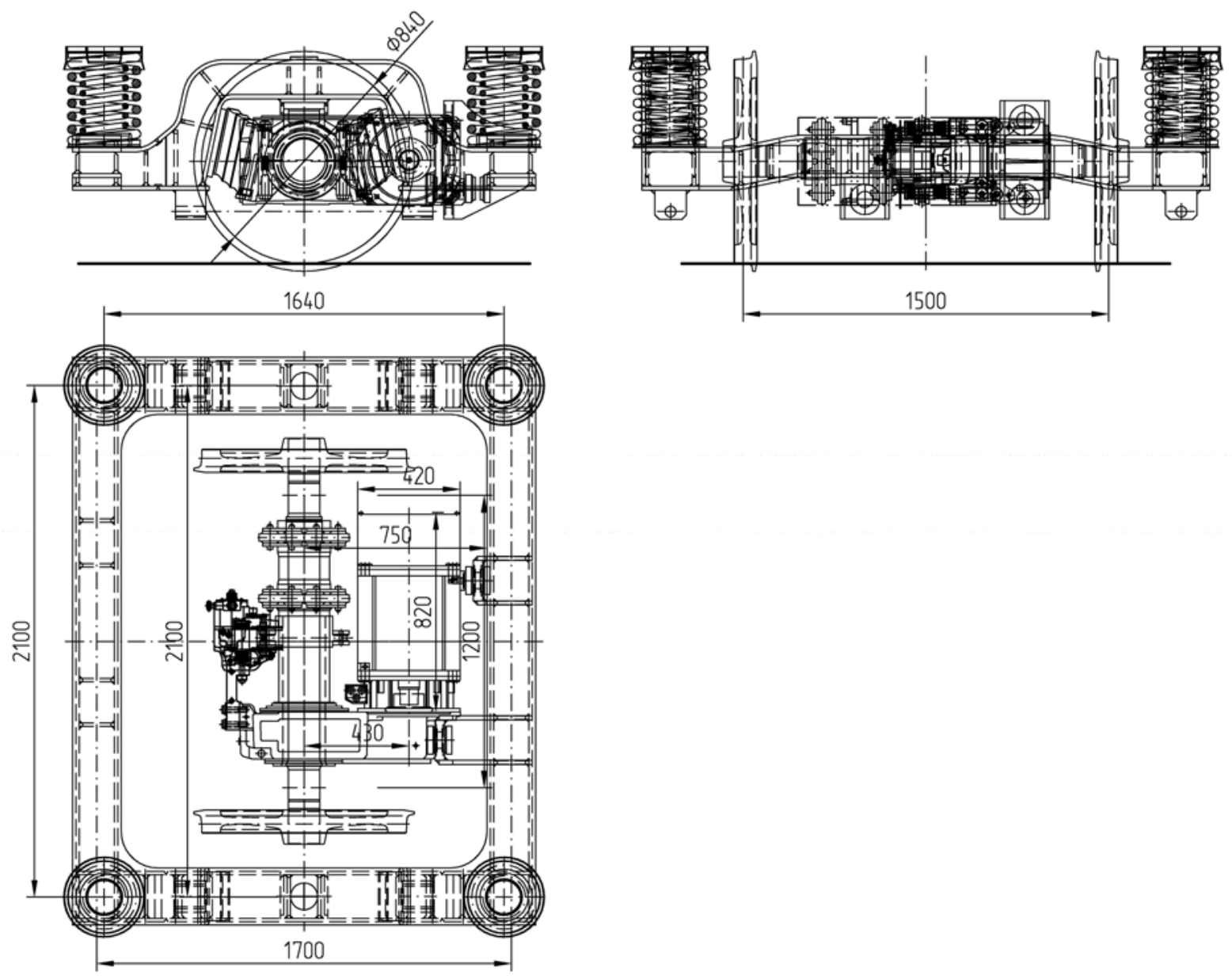

Rys.10. Koncepcja wózka jednoosiowego z silnikiem trakcyjnym i przekładnią osiową mocowaną na ramie wózka oraz wałem drążonym (oparcie pudła na wózku za pośrednictwem sprężyn śrubowych) 

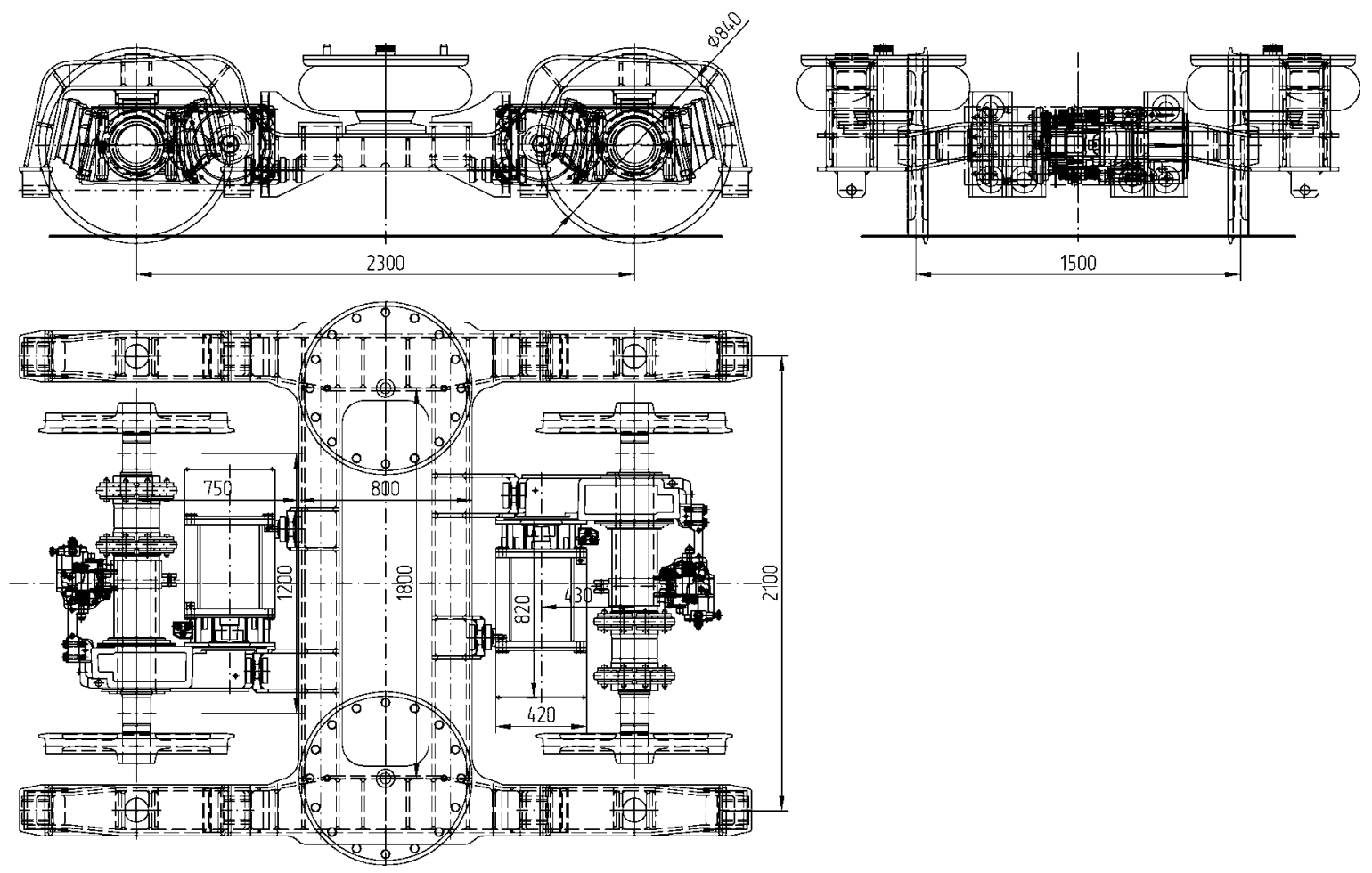

Rys.11. Koncepcja wózka dwuosiowego z silnikiem trakcyjnym, przekładnią osiową mocowaną na ramie $\mathrm{i}$ wałem drążonym (oparcie pudła na wózku za pośrednictem sprężyn pneumatycznych)

Koncepcję rozmieszczenia urządzeń układu napędowego dla wybranych wariantów autobusów szynowych przedstawiono na rys.12 i 13.
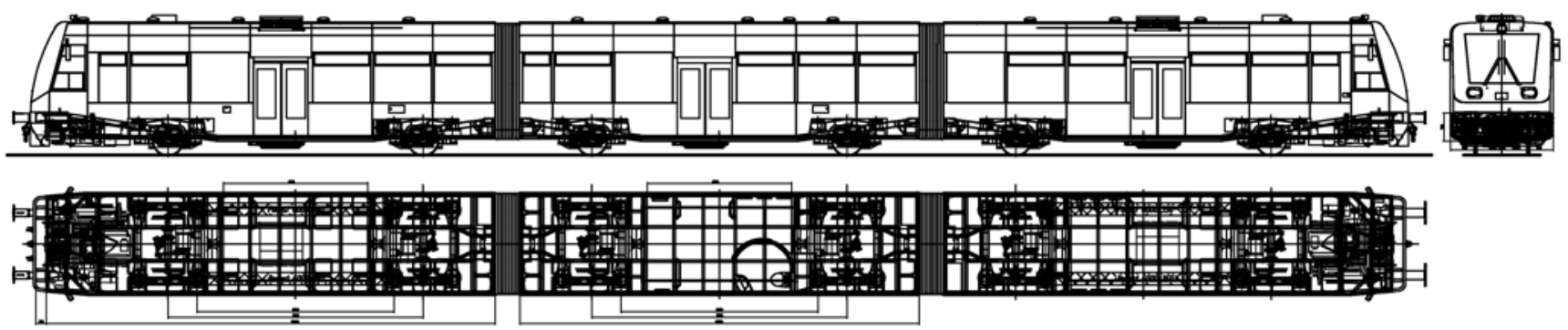

Rys.12. Koncepcja zabudowy układów napędowych w autobusie szynowym typu 210M z wykorzystaniem wózków jednoosiowych

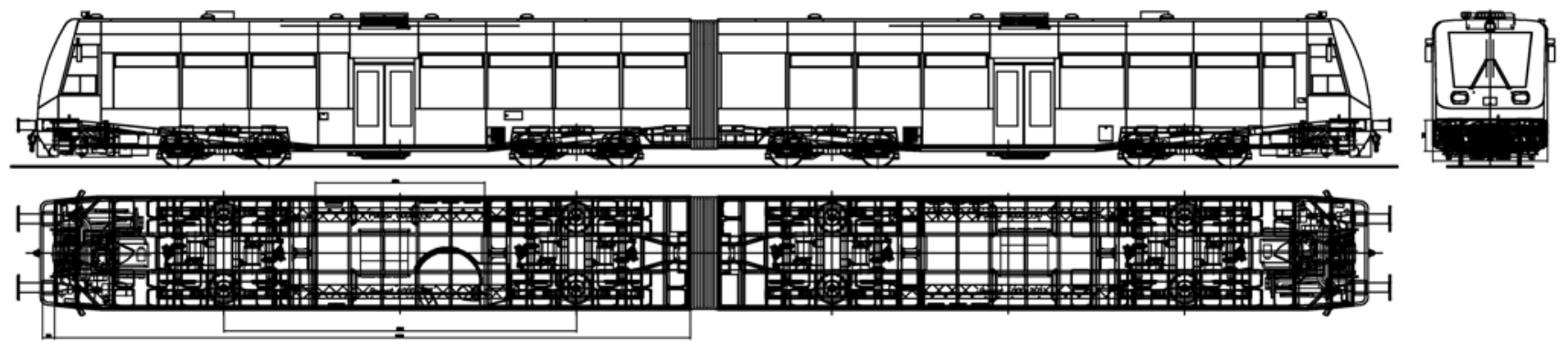

Rys.13. Koncepcja zabudowy układów napędowych w autobusie dwuczłonowym z wykorzystaniem wózków dwuosiowych 


\subsection{Koncepcja i założenia projektowe dla spalino- wo-elektrycznego układu napędowego do za- budowy wewnątrz pojazdu}

Propozycje rozmieszczenia zespołu mocy dla koncepcji układu napędowego wewnątrzpojazdowego mogą być rozwiązane dwuwariantowo [4]:

- wariant pierwszy identyczny jak dla koncepcji układu podpodłogowego przedstawionego na rys.4.

- wariant drugi, w którym proponuje się dwie gałęzie, a z każdej zasilanie dwóch silników trakcyjnych $\mathrm{z}$ oddzielnego przekształtnika napędowego.

W wariancie pierwszym proponuje się następujący układ:

- silnik spalinowy (wersja stojąca) o mocy około $560 \div 620 \mathrm{~kW}$

- prąanica trójfazowa synchroniczna o mocy około $550 \div 600 \mathrm{~kW}$

- prostownik diodowy

- falownik napędowy o mocy $600 \mathrm{~kW}$

- przekształtnik hamowania o mocy $400 \mathrm{~kW}$

- opornice hamowania o mocy ok. $400 \mathrm{~kW}$

- przetwornica statyczna $660 \mathrm{~V} / 3 \times 400 \mathrm{~V} / 24 \mathrm{~V}$ DC o mocy $20 \div 25 \mathrm{~kW}$

- silniki trakcyjne dla napędu:

- obydwu wózków dwuosiowych o mocy 100 kW każdy

- tylko jednego wózka o mocy $200 \div 220 \mathrm{~kW}$.

Lekki pojazd szynowy oparty byłby tylko na wózkach dwuosiowych, a konfiguracje układów przeniesienia momentu obrotowego na zestawy kołowe mogłoby być identyczne jak przedstawiono na rys. $7 \mathrm{i}$ 8 .

Wariant drugi przedstawiony na rys.14 składałby się z:

- silnika spalinowego, prądnicy głównej synchronicznej, prostownika diodowego i przetwornicy statycznej o parametrach jak dla wariantu pierwszego

- przekształtnika napędowego, opornic hamowania i silników trakcyjnych jak dla wersji napędu podpodłogowego, przy czym moc przekształtnika powinna wynosić ok. $300 \mathrm{~kW}$, a moc silników trakcyjnych $100 \div 120 \mathrm{~kW}$ każdy.

W wariancie tym silnik spalinowy, prądnica, prostownik oraz pozostałe zespoły winny być zabudowane w module napędowym za kabiną sterownicza, przy czym dostęp do nich wienien być $\mathrm{z}$ dwóch stron: $\mathrm{z}$ zewnątrz pojazdu oraz $\mathrm{z}$ jego wnętrza od strony korytarza.

Koncepcje przedziału, a w zasadzie modułu napędowego, przedstawiono na rys.15, a zabudowy jego we wnętrzu autobusu jedno- i dwuczłonowego na rys. 16 i 17.

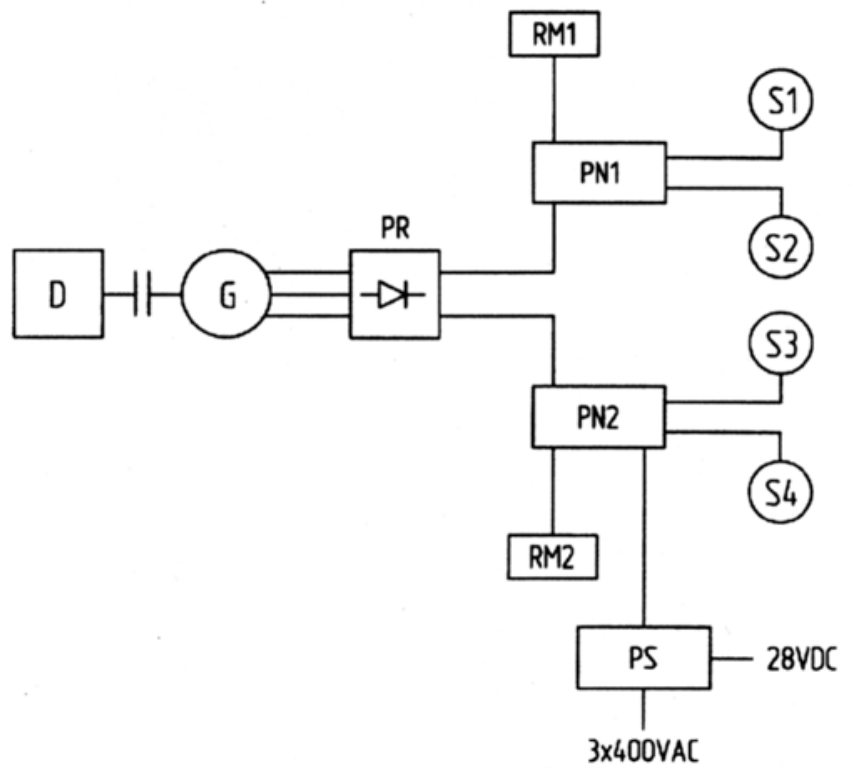

Rys.14. Schemat ideowy układu elektrycznego lekkiego pojazdu szynowego: D - silnik spalinowy; G - trójfazowa prądnica synchroniczna; PR - prostownik; PN1, PN2 przekształtniki napędowe; RM1, RM2 - rezystory hamowania oporowego; S1 $\div$ S4 - silniki asynchroniczne; PS przetwornica statyczna

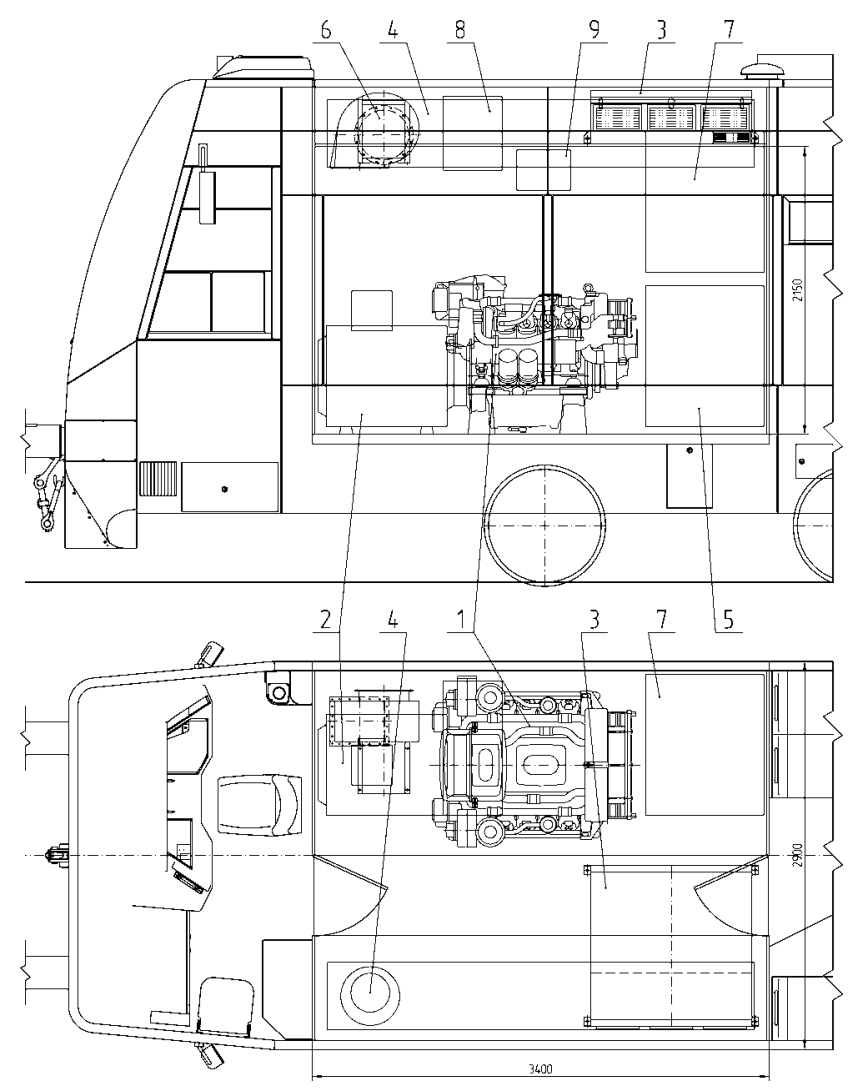

Rys.15. Koncepcja modułu napędowego wewnętrznego: 1 silnik spalinowy; 2 - prądnica główna; 3 - przekształtnik napędowy (falownik, przekształtnik hamulca, prostownik); 4 - thumik wylotu spalin; 5 - szafa sterująca; 6 - wentylator; 7 - zespół chłodnic.; 8 - zbiornik wyrównawczy 

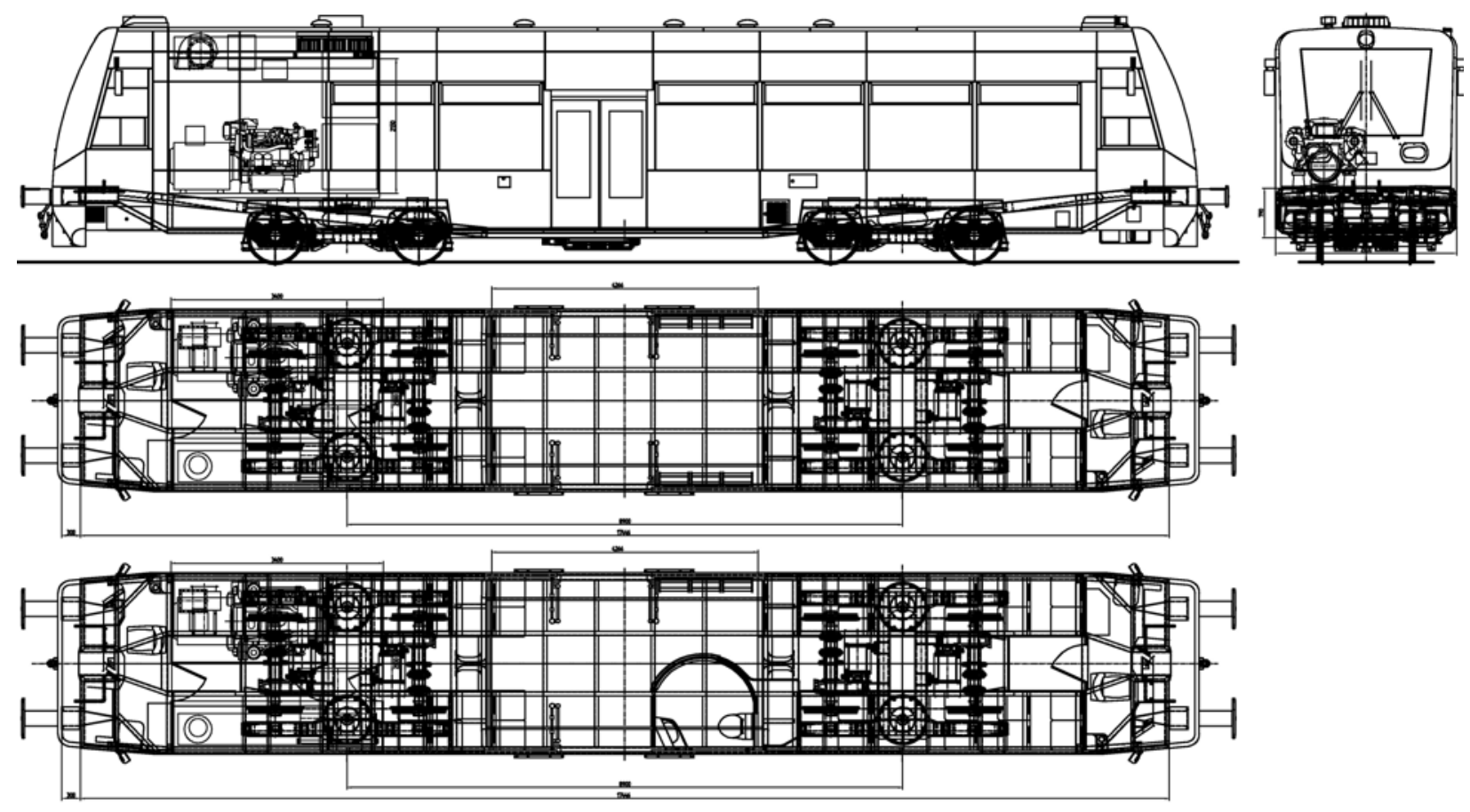

Rys.16. Koncepcje zabudowy modułu napędowego w autobusie jednoczłonowym

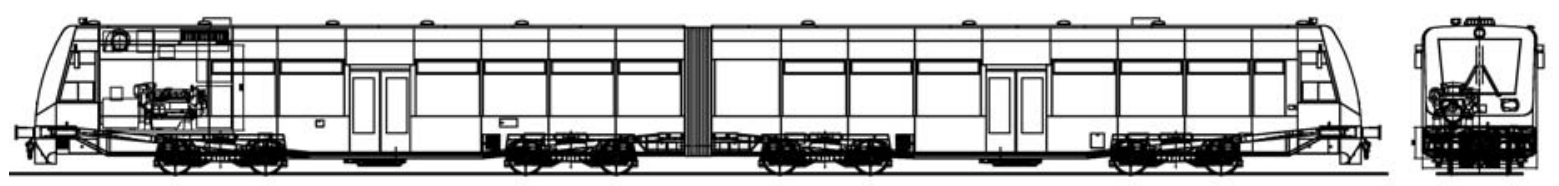

Rys.17. Koncepcja zabudowy modułu napędowego w autobusie dwuczłonowym

Ostateczny wybór układu napędowego zostanie dokonany po szczegółowej analizie rynku i zapotrzebowaniu na takie rozwiązania. Obecnie można wstępnie stwierdzić, że najlepszym rozwiązaniem krajowych spalinowo-elektrycznych układów napędowych będą propozycje typu power-pack, a więc do zabudowy pod pojazdami i częściowo na dachach.

Takie układy będą cenowo korzystniejsze, ponieważ konstrukcje podwozi wraz $\mathrm{z}$ wyposażeniem wewnętrznym są już do dyspozycji.

\section{ZAKOŃCZENIE}

Spalinowo-elektryczne układy napędowe lekkich pojazdów szynowych (w tym autobusów szynowych) decyduja przede wszystkim o ich możliwościach trakcyjnych. Ważnym jest dla nich przede wszystkim ich trwałość, niezawodność oraz wysoka podatność obsługowo-naprawcza.

Mimo tego, że dotychczas najczęściej stosowanym układem napędowym w autobusach szynowych jest układ złożony z silnika spalinowego, przekładni głównej hydraulicznej (hydromechanicznej), wałów przegubowych i przekładni osiowych (z nawrotnikiem lub bez w zależności od typu zastosowanej przekładni głównej) to ostatnio coraz częściej stosowany jest napęd spalinowo-elektryczny.

Napęd ten, ze względu na swoje walory użytkowe będzie podstawowym układem w lekkich pojazdach szynowych o wiekszej mocy oraz przeznaczonych do jazdy $\mathrm{z}$ większymi prędkościami.

Zaprezentowane propozycje, koncepcje i założenia dla krajowych układów napędowych spalinowoelektrycznych wychodzą naprzeciw przyszłym projektom konstrukcyjnym, zwłaszcza autobusów szynowych dla przewozów regionalnych i podmiejskich dla władz samorządowych zainteresowanych takimi rozwiązaniami.

Podstawową zaletą prezentowanych układów jest to, że poza silnikami spalinowymi (zarówno leżącymi jak i stojącymi) o wysokich wymaganiach, pozostałe maszyny, zespoły i urządzenia są już produkowane $\mathrm{w}$ kraju lub też mogą być potencjalnie uruchamiane przez producentów krajowych. O wszystkim jednak zadecyduje ekonomia, a więc zapotrzebowanie na takie konfiguracje napędów. 


\section{LITERATURA}

[1] Marciniak Z.: Przeglad lekkich wieloczłonowych pojazdów szynowych z napędem spalinowo-elektrycznym. Pojazdy Szynowe nr 2/2006.

[2] Marciniak Z.: Koncepcja spalinowoelektrycznych układów napędowych dla lekkich pojazdów szynowych. Materiaty XVII Konferencji Naukowej „Pojazdy Szynowe”, Kazimierz Dolny $2006 r$.

[3] Marciniak Z. , Sienicki A.: Wybór parametrów spalinowo-elektrycznego uktadu napędowego dla lekkiego pojazdu szynowego na podstawie obliczeń $i$ badań symulacyjnych. Pojazdy Szynowe $n r$ 4/2006 $r$.

[4] Praca zbiorowa pod kierunkiem Z. Marciniaka: Wymagania $i$ wytyczne dla nowoczesnego spalinowo-elektrycznego zespotu napędowego oraz koncepcje i zatożenia możliwych rozwiqzań dla krajowego zespotu napędowego. Projekt badawczy KBN nr 4T12D01227. Praca niepublikowana. IPS , Tabor”, Poznań 2005 r.
[5] Karta UIC 505-1. Pojazdy kolejowe. Skrajnia pojazdów. Wyd. 10, $05.2006 r$.

[6] Karta UIC 518. Badania $i$ homologacja pojazdów kolejowych $z$ punktu widzenia właściwości dynamicznych, bezpieczeństwa jaz$d y$, obciażenia toru $i$ parametrów biegowych. Wyd. 3, 08.2005 r.

[7] Karta UIC 515-0. Tabor dla transportu pasażerskiego. Wózki - Układy biegowe. Wyd. 2, $04.2001 r$.

[8] Karta UIC 624. Badanie emisji gazów wydechowych silników spalinowych trakcyjnych. Wyd. 3, $02.2006 r$.

[9] Norma PN-EN 12663:2002. Kolejnictwo. Wymagania konstrukcyjno-wytrzymałościowe dotyczqce pudet kolejowych pojazdów szynowych.

[10] Norma PN-92/K-11000. Tabor kolejowy. Hatas. Ogólne wymagania i badania. 